\title{
Bushmeat networks link the forest to urban areas in the trifrontier region between Brazil, Colombia, and Peru
}

\author{
$\underline{\text { Nathalie van Vliet }}^{1}, \underline{\text { Maria Paula Quiceno }}^{2}, \underline{\text { Daniel Cruz }}^{2}, \underline{\text { Lindon Jonhson Neves de Aquino }}^{3}, \underline{\text { Blanca Yagüe }}^{4}, \underline{\text { Tatiana Schor }}^{5,6}, \underline{\text { Sara }}^{\text {Bathande }}$ \\ Hernandez $^{7}$ and Robert Nasi ${ }^{1}$
}

\begin{abstract}
Recent studies have intended to quantify urban consumption and trade in Amazonian towns. However, little is still known about the different ways in which bushmeat is made available in urban areas, including commercial and noncommercial flows, and how those flows contribute to link forests to urban livelihoods. In this study we qualitatively describe the structure and functioning of bushmeat flows in terms of species, catchment area, stakeholders involved, and the motivations for their activity in the main towns of the Amazon trifrontier region between Brazil, Colombia, and Peru. We show that bushmeat trade to urban areas exists under an organized but invisible commodity chain providing a source of income to about 195 persons. Bushmeat is made available either directly from the hunter to the urban consumer, at the main market place, or in food stalls and restaurants. On the Colombian border, the trade is totally invisible, whereas in Peru and Brazil, bushmeat is sold in open markets despite regulations. The catchment area comprises the main rivers: up to Caballococha along the Amazon River, along the Atacuary River in Peru, along the Javari River between Peru and Brazil, and along the Loretoyacu and Amacayacu rivers in Colombia and in periurban forests. Although the trade is rather localized (no commercial flows to larger towns), international transborder trade is commonplace, disregarding Convention on International Trade in Endangered Species of Wild Fauna and Flora regulations. Bushmeat clients in urban areas are mainly nonindigenous or mestizos who can afford bushmeat as a luxury meal. Instead, indigenous people in urban areas do not access bushmeat through the market but rather through their social networks with whom they maintain noncommercial flows including immediate exchange and long-term exchange mechanisms. Although bushmeat is no longer consumed as a daily meal among urban and periurban indigenous families, it constitutes what could be called a "festival food," referring to the use of food to express cultural values and origin. These results highlight the need to differentiate bushmeat trade and noncommercial flows of bushmeat in law enforcement activities. Indeed, although bushmeat trade is banned in all three countries, subsistence use is allowed. Bushmeat consumption contributes to urban subsistence when it is obtained as a gift, and this pattern is increasingly characteristic among mobile and multisited indigenous households in urban Amazon.
\end{abstract}

Key Words: Amazon; bushmeat; exchange networks; indigenous people; trade; urban areas

\section{INTRODUCTION}

Nowadays, more than 70\% of the Brazilian Amazon's population lives in cities (IBGE 2010), and urbanization has recently emerged as a driving force of transformation in forested areas far from frontiers in the Amazon (Guedes et al. 2009, Nasuti et al. 2015). Regional and international economies and better access to transportation and information have driven migration between rural and urban areas (Alexiades 2009, Pinedo-Vasquez and Padoch 2009). Many households have also migrated to the city or settled near urban areas for educational and health services (Parry et al. 2010). Inevitably, the contact with urban lifestyles leads to increased dependency on goods and services (Peluso and Alexiades 2005) and comes along with the adoption and incorporation of urban cultural models (Mainbourg et al. 2002). However, these cultural transitions do not necessarily lead to the total demise of rural links, because migrating groups often maintain a link to the forest through rural-urban networks (Eloy et al. 2014). Mobility and increasing interactions with urban areas extend rural social networks to incorporate local towns and regional cities, strengthening indigenous social capital (Bernal and Mainbourg 2009). These multisited households often continue their economic activities in rural areas while depending on income from urban activities.

Recent studies on forest resources use (Eloy and Lasmar 2012) and fishing (Sobreiro 2015) demonstrate how growing interdependency between rural and urban spaces represents both an opportunity and a challenge for natural resources management and rural livelihoods, strengthening indigenous governance but also challenging current models for natural resources management based on permanent rural residence. In this study we focus on bushmeat use, traditionally well rooted in rural lifestyles, to illustrate the persistence of forests in urban livelihoods through commercial and noncommercial networks. Bushmeat is defined as wild animals, including mammals, amphibians, insects, reptiles, and birds but excluding fish or aquatic molluscs, hunted or harvested in tropical and subtropical countries for food (CBD 2011). Despite the rapid social and economic transformations that push rural livelihoods away from the dependency on forest products (Nardoto et al. 2011, Sills et al. 2011), bushmeat in rural communities of the Amazon remains an important component of household food security and income, not necessarily in terms of quantities, but as a key element in diet, income diversification, and social and cultural roles (Ojasti 2000, Bodmer and Lozano 2001, Bodmer et al. 2004, Sirén 2012). The numerous studies available on bushmeat in the Amazon have focused on understanding bushmeat use and sustainability in rural contexts (Bodmer et al. 1997, Fragoso et al. 2000, Hill et al. 2003, Silvius et al. 2004, Sirén et al. 2004, Damania et al. 2005, Levi et al. 2009). However, sustainability hinges on the feedbacks and balances between social and ecological systems (Ostrom 2007), and studies should incorporate the emerging social dynamics that influence bushmeat use.

${ }^{1}$ Center for International Forestry Research, ${ }^{2}$ Fundación Science International, ${ }^{3}$ Universidade Federal do Amazonas, ${ }^{4}$ Independent consultant, ${ }^{5}$ Geography Department, Federal University of Amazonas, ${ }^{6} \mathrm{NEPECAB},{ }^{7}$ Independent Expert in Environmental Economics 
Fig. 1. Map of the study area: the Amazonian trifrontier region.

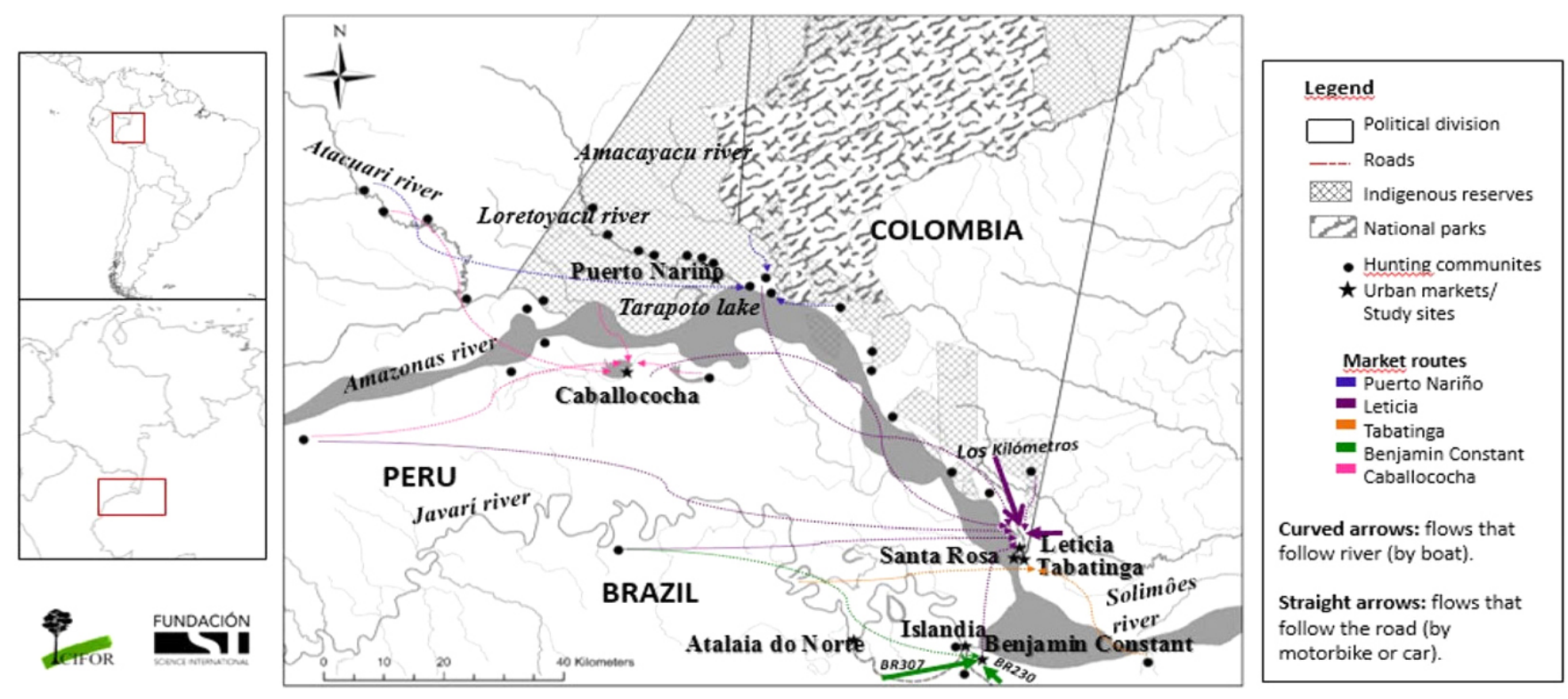

Although bushmeat flows from the forests to urban areas in the Amazon were long considered insignificant, largely because of the greater availability of alternative domestic protein sources (Rushton et al. 2005), recent studies have found evidence of the existence of bushmeat markets: Iquitos-Peru (Rushton et al. 2005), Pompeya-Ecuador (WCS 2007), and Abaetetuba-Brazil (Baía et al. 2010). Parry et al. (2014) examined the scale and drivers of urban wildlife consumption in the forested prefrontier of Brazilian Amazonia and found that bushmeat was eaten at least once a month by nearly half of urban households. A recent paper on the trifrontier region describes the species and volumes of bushmeat sold in the main towns of the region (van Vliet at al. 2014). The study showed that 473 tons of bushmeat are potentially traded per year in market places from the main trifrontier towns, which when taken to the total urban population size of the area equals $3.2 \mathrm{~kg}$ per capita per year, a number comparable to numbers found in Central African urban areas. Buying and selling wildlife are illegal in all Amazonian countries; thus, commercialization of bushmeat in urban centers largely occurs in secreted selling points, making information on bushmeat trade difficult to obtain (Sampaio 2003, Bodmer et al. 2004). Until recent years, most of the available data on bushmeat trade in towns from the Amazon were limited to those obtained through confiscations by environmental agencies.

Despite the increased evidence of the existence of bushmeat flows from rural to urban areas in the Amazon, most of the studies have focused their attention on quantifying volumes and describing the species concerned in the trade. However, to our knowledge, no study has taken a wider approach to describe the networks that link rural to urban areas through bushmeat commercial and noncommercial flows. Noncommercial flows correspond to bushmeat taken from rural areas to family members or members of the same social group living in towns. Taking both commercial and noncommercial flows into consideration is important to disentangle subsistence and commercial use of bushmeat in urban areas and provide sound policy recommendations to address urban bushmeat consumption. Therefore, the objective of this study was to describe the structure and functioning of commercial and noncommercial flows of bushmeat through a set of complementary methods, including participatory observation, surveys, semistructured interviews, and ethnographic observation conducted in the trifrontier region between Brazil, Peru, and Colombia. In this study, we do not present results on volumes traded because that information is already available in the paper by van Vliet et al. (2014).

\section{MATERIAL AND METHODS}

Study site

The study was carried out in 2012-2013 at the trifrontier region between Colombia, Peru, and Brazil, in eight localities (Fig. 1). Two were in Colombia, Leticia (37,832 inhabitants) and Puerto Nariño (6983 inhabitants); two were in Peru, Caballococha (7885 inhabitants) and the Santa Rosa and Atacuari river communities; and three were in Brazil, Tabatinga (52,272 inhabitants), Benjamin Constant (33,411 inhabitants), and Atalaia do Norte $(15,153$ inhabitants; DANE 2007, INEI 2008, 2011, IBGE 2010). Leticia forms a single agglomeration with the neighboring city of Tabatinga on the Brazilian side and is also closely connected to communities and urban areas on the Peruvian side just across the Amazon River. Commodities and people travel across frontiers by boat or by plane. Despite this relative isolation, the region is increasingly globalized with manufactured goods and food products coming from different parts of Latin America: frozen chicken from southeast and southern Brazil (Nardoto et al. 2011); live cows from the Putumayo region (Colombia) and Santarem (Pará, Brazil); vegetables from the peruvian Andes; and cheap industrial items, such as pans, buckets, and clothes, from Bogotá and Panamá.

The population in the study is the result of different migration waves from a mixture of origins: indigenous (Ticuna, Yagua, Cocama, Huitoto), white, and mestizos (INEI 2010, Suárez- 
Table 1. Numbers of interviews developed and total of stakeholders identified.

\begin{tabular}{|c|c|c|c|c|}
\hline \multicolumn{2}{|c|}{ Country \& City } & \multirow{2}{*}{$\begin{array}{l}\text { Users } \\
\text { Hunters }\end{array}$} & \multirow{2}{*}{$\begin{array}{c}\begin{array}{c}\text { Number of } \\
\text { interviews developed }\end{array} \\
8\end{array}$} & \multirow{2}{*}{$\begin{array}{c}\begin{array}{c}\text { Total of actors } \\
\text { identified }\end{array} \\
40\end{array}$} \\
\hline Colombia & Puerto Nariño and Loretoyacu river & & & \\
\hline & communities & Market sellers & 2 & 1 \\
\hline & & Restaurants (formal) & 5 & 5 \\
\hline & & Restaurants (informal) & 2 & 2 \\
\hline & Leticia & Hunters & 7 & 8 \\
\hline & & Market sellers & 3 & 6 \\
\hline & & Restaurants (formal) & 4 & 5 \\
\hline & & Restaurants (informal) & 4 & 6 \\
\hline \multirow[t]{8}{*}{ Peru } & Caballococha and Atacuari river & Hunters & 9 & 20 \\
\hline & communities & Market sellers & 6 & 9 \\
\hline & & Restaurants (formal) & 3 & 6 \\
\hline & & Restaurants (informal) & 8 & 15 \\
\hline & Santa Rosa & Hunters & & 1 \\
\hline & & Restaurants (formal) & & 2 \\
\hline & & Restaurants (informal) & & 1 \\
\hline & Islandia & Market sellers & & 2 \\
\hline \multirow[t]{9}{*}{ Brazil } & Tabatinga & Hunters & 1 & 3 \\
\hline & & Market sellers & 1 & 6 \\
\hline & & Restaurants (informal) & & 1 \\
\hline & Benjamin Constant & Hunters & 23 & 31 \\
\hline & & Market sellers & & 5 \\
\hline & & Restaurants (formal) & 2 & \\
\hline & & Restaurants (informal) & & 3 \\
\hline & Atalaia do Norte & Hunters & 7 & 12 \\
\hline & & Market sellers & & 5 \\
\hline \multicolumn{3}{|c|}{ Number of interviews developed $\&$ total of actors identified } & $95(49 \%)$ & 195 \\
\hline
\end{tabular}

Mutis et al. 2010). Nowadays, the local rural economy relies mainly on shifting cultivation (chagras), hunting, fishing, tourism, timber extraction, and drug trafficking (Riaño 2003, Zarate 2008). In the urban towns of the trifrontier, the local economy relies on governmental subsidies, illicit drug traffic, wood extraction, small businesses, and tourism. The periurban area of Leticia is located along the only road that extends outside the city for $20 \mathrm{~km}$ toward the northwest. It is characterized by the presence of several multiethnic indigenous communities founded in the 1960s. Being located very close to the urban area, these indigenous communities have a periurban lifestyle combining rural activities such as agriculture, gathering, fishing, and hunting with urban activities such as studying or working in town.

\section{Methods}

Our methodology relied on a twofold approach. One analyzed the bushmeat trade chain, and the other aimed at qualitatively describing noncommercial flows of bushmeat from rural to urban areas.

\section{Bushmeat commercial trade chain}

To understand the bushmeat commercial trade chain, i.e., the stakeholders involved, their relationships, and the functioning of the trade, the study combined a diversity of approaches including participatory observation and semistructured interviews (Appendices 1, 2, and 3). Given the fact that bushmeat trade occurs in hidden channels, we spent three to four months in 2012 exclusively observing the market, discussing it with consumers, identifying and approaching the traders through informal discussions, sharing meals, and traveling around to potential source areas. This investment of time was crucial to gain the confidence of different stakeholders and gather qualitative information on the sale points, the typology of stakeholders in the chain (from the hunters to the urban consumers), the main trade routes, and the means of transportation so as to define the overall catchment area and the relationships among stakeholders.

Once we had an exhaustive idea of the existing sale points and had developed a collaborative relationship with the different stakeholders in the chain, we gathered more in-depth information at three main levels of the chain: the hunters, the market sellers, and the restaurants and food stalls. We developed two types of semistructured interviews: one designed for the hunters and another designed for market sellers and restaurants.

Semistructured interviews were carried out with 55 out of the 115 hunters $(48 \%$ ) participating in the trade (Table 1, see Appendix 1 for questions asked). A total of 12 market sellers were interviewed out of the 34 selling bushmeat in the markets (35\%), as well as 14 formal restaurants and 14 informal restaurants (street food stalls) out of the 46 that sell bushmeat (61\%). See Appendices 2 and 3 for questions asked.

\section{Noncommercial bushmeat flows}

We described bushmeat networks from a social and cultural perspective using an ethnographic approach, combining semistructured interviews, participant observation, and visits to bushmeat exchange places. The aim of the ethnographical approach is to understand social phenomena from the perspective of their actors (Guber 2001). The families sampled were selected using purposive sampling (Maxwell 2008); they were deliberately 
selected because of the importance and representativeness of the information they could provide. The choice of the families was also driven by the degree of trust that the researchers could build to discuss about bushmeat flows to urban areas, which is a sensitive topic. For those reasons, we chose to focus only on the Colombian side, using families with whom we had worked on bushmeat and food security in the context of previous research. Our sample consisted of three families that shared some common characteristics (multiethnic but predominantly indigenous, diversified livelihoods, well connected to urban lifestyle), but that differed in that they were located along a periurban to urban continuum. Family 1 was a periurban indigenous household with strong and direct links to the forest and the city, family 2 was a urban indigenous household with strong links to the forest, and family 3 was an urban indigenous household with less directly forest-related livelihoods. These families were characteristic in their different levels of integration to urban lifestyles and different levels of connections to forest-related livelihoods.

The three families were initially characterized during prearranged visits, where semistructured interviews were carried out to characterize the household in terms of the age and gender of the most permanent members, their origin, and their ethnic identity, as well as to gain a general understanding of the main economic activities of the household members. From January to December 2013, visits to each household were arranged on a regular basis, following a participant observation approach. In addition, the researchers asked the household members to call them, particularly when bushmeat arrived at the house, so that the researchers could participate in the process of preparation, cooking, and consumption of bushmeat and ask about the species and origin of the meat. Researchers were also informed when different activities involving bushmeat were going to take place and participated in three mingas (communal work), one dance ritual, several airport visits, and hunting journeys into the forest. In addition, one of our researchers lived for a month (April 2013) with family 2 , and more specific data about daily protein consumption were registered. We registered every occasion on which bushmeat was hunted, traded, exchanged, shared, or consumed by any of the family members. We added to this information further information about the network of stakeholders involved, paying particular attention to the person responsible for each action and the type of interaction established. Moreover, we visited the families and went with them to the different places where bushmeat was pursued, exchanged (either given or received), traded (bought or sold), and consumed. During fieldwork, informal conversations took place among hunters, sellers, and consumers of bushmeat, adding relevant details to our understanding of bushmeat transactions within indigenous networks. To ensure the "trustworthiness" of our research (Marshall and Rossman 2011), we triangulated our results with those obtained on simultaneously in the same region by van Vliet et al. 2014.

\section{RESULTS}

\section{Species in commercial and noncommercial flows of bushmeat in} urban areas

The most commonly hunted species by Colombian hunters are agouti(Dasyproctafuliginosa) and paca (Cuniculus paca), whereas Brazilian hunters mainly capture paca, tarecaya turtle
(Podognemis unifilis), curassows (Crax sp.), and tapirs (Tapirus terrestris). The most commercialized species in Brazilian markets are paca, tapir, and the collared peccary (Pecari tajacu). In Peruvian markets paca and the yellow-footed tortoise (Chelonoidis denticulata) are the most traded species, whereas in Colombia paca was the species most commonly commercialized. The list of animals that are mostly obtained through nonmonetary flows in urban areas are tortoises, deer, a wide variety of birds (e.g., Ara spp.), several monkey species, paca, and white-lipped peccary. Insects such as beetle larvae or mojojoi (Rhynchophorus palmarum) and ants (Atta spp.) are also frequently exchanged or given as gifts.

\section{Catchment area and geographic origin of bushmeat flows}

According to the stakeholders of the trade chain, flows of bushmeat to urban areas are constrained by the number of active hunters, the costs of transportation and hunting tools, and control operations, and vary according to the availability of fish and urban demand. These factors determine the length and the intensity of the commercial flow. Each urban center is provisioned with bushmeat from specific trade routes. The most important trade routes providing urban markets with bushmeat are (1) from the Javari River to Atalaia do norte, Benjamin Constant and Tabatinga; (2) from Peruvian villages in the Atacuari and Amazon River to Caballococha; (3) from communities along the Loretoyacu and Amacayacu rivers, wetlands of Tarapoto lakes to Puerto Nariño and (4) from periurban areas to Leticia, Tabatinga, Atalia do Norte, and Benjamin Constant (Fig. 1). No commercial flows of bushmeat occur outside the study area to larger towns, indicating that the trade is relatively local, but international transborder trade is very common. Concerning noncommercial flows, bushmeat is sent by rural members of the families either by boat from communities along the rivers or by plane on weekly flights from La Pedrera to Leticia. Bushmeat is also obtained directly from periurban forests or shifting cultivation plots.

\section{Stakeholders involved in the bushmeat commercial trade chain}

\section{The hunters}

A total of 115 hunters were identified as actively participating in the bushmeat trade chain in the trifrontier. Among the hunters interviewed, the majority of periurban hunters were colonos or mestizo, whereas hunters living in rural communities were indigenous (Table 2). The majority of the hunters we interviewed alternated hunting with other economic activities such as agriculture and fishing, but also logging, carpentry, farm caretaking, grocery trading, and laboring for daily wage salaries in construction sites. Only $25 \%$ of hunters interviewed $(n=14)$ relied solely on hunting as their economic and subsistence activity. The proportion between bushmeat sold and bushmeat consumed, as well as the level of participation in the bushmeat market chain, allowed us to identify "specialized" and "diversified" hunters. Specialized hunters sell $90 \%$ of bushmeat caught to known regular clients in the city (families, teachers, public employees, traders, workers) or intermediaries that visit their communities, as in the Atacuari River region. These specialized hunters are well connected to wholesalers who guarantee the purchase of the meat. Diversified hunters consume $65 \%$ of their total catch with their family and friends, and their sales are more occasional and opportunistic. They sell directly to the final consumers within the 
periurban area or inside the community using cell phones to inform their clients about the availability of bushmeat, avoiding intermediaries and potential controls from environmental authorities. The main incentive for hunting is subsistence, with bushmeat being either a direct source of food or a means to obtain money to buy food and beverages, basic products, and hunting supplies. Additional incentives such as healthy nutrition and pleasure were reported. Differences in frequency of hunting, hunting tools, effort, and success show that specialized hunters spend more days per hunting trip and use more cartridges, which results in much higher offtakes than those observed for diversified hunters (Table 3).

Table 2. Locality and ethinc group of the hunters interviewed.

\begin{tabular}{lllc}
\hline \hline Country & Locality & Ethnic Group & $\begin{array}{c}\text { Number of hunters } \\
\text { interviewed }\end{array}$ \\
\hline Colombia & Puerto Nariño & Indigenous & 8 \\
& Leticia & Indigenous & 5 \\
& Mestizo & 2 \\
Peru & Atacuari River & Indigenous & 9 \\
Brazil & Benjamin & Mestizo/ & 23 \\
& Constant & Caboclo & \\
& Atalaia do & Mestizo/ & 7 \\
& Norte & Caboclo & \\
& Tabatinga & Mestizo/ & 1 \\
& & Caboclo & 55 \\
Total & & & \\
\hline
\end{tabular}

Table 3. Description of practices of diversified and specialized hunters (average figures).

\begin{tabular}{cccccc}
\hline \hline Type of \\
hunter/ & $\begin{array}{c}\text { Mean } \\
\text { cartridges } \\
\text { per } \\
\text { hunting } \\
\text { trip }\end{array}$ & $\begin{array}{c}\text { Mean } \\
\text { number } \\
\text { of preys } \\
\text { caught } \\
\text { per } \\
\text { hunting } \\
\text { trip }\end{array}$ & $\begin{array}{c}\text { Mean } \\
\text { number } \\
\text { of } \\
\text { hunting } \\
\text { trips per } \\
\text { month }\end{array}$ & $\begin{array}{c}\text { Mean } \\
\text { number } \\
\text { of days } \\
\text { per } \\
\text { hunting } \\
\text { trip }\end{array}$ & $\begin{array}{c}\text { Mean } \\
\text { number of } \\
\text { cartridges } \\
\text { bought } \\
\text { per month }\end{array}$ \\
\hline $\begin{array}{c}\text { Diversified } \\
\text { hunters }\end{array}$ & 7.7 & 3.5 & 3.5 & 2.24 & 24 \\
$\begin{array}{c}\text { Specialized } \\
\text { hunters }\end{array}$ & 16.4 & 7.4 & 3.7 & 4.6 & 44 \\
\hline
\end{tabular}

Intermediaries, market sellers, restaurants, and street food stalls A total of 34 market sellers, 18 formal restaurants, and 28 informal restaurants were identified as participating in the trade chain. Market sellers are most often mestizos or indigenous who had been active in the trade for more than 15 years. They are usually men in Brazilian and Colombian markets, and women in Caballococha, Peru. Selling bushmeat in restaurants and food stalls is usually a female activity. Traders usually contact hunters directly by cell phone and buy bushmeat at the hunter's house. On a daily basis, they sell the meat directly to known consumers door to door, to restaurants, or to market traders that purchase bushmeat at the harbor or close to the market in the early morning. Market traders have fixed stalls that involve monthly rental fees, public services, and costs of refrigerators, ice, salt, fuel, and transport. Usually they store bushmeat at home or in refrigerators at the harbor or at the market place. Market traders diversify the sale of bushmeat with fish (mostly skin fish) in Leticia and Atalia do Norte, and with chicken and even clothing in Caballococha. Bushmeat trade is considered to be a very good business but also perceived as very risky given the illegality context. According to the traders, their main clients are nonindigenous consumers, who can afford luxury meats. Traders also report that indigenous households consume bushmeat regularly but usually get the bushmeat directly from periurban forests or from their relatives in their rural community of origin. Restaurants get bushmeat from market sellers and trusted hunters. One-third of the dishes sold are with bushmeat, and the rest are usually with chicken, livestock, and fish. Formal restaurants selling bushmeat are common in Santa Rosa, Peru, and along the periurban road of Los Kilometros, open most often during the weekend. Food stall owners sell in the harbor or near the market places. Formal restaurants usually sell bushmeat to medium- and high-income nonindigenous customers, civil servants, and tourists, whereas informal street food stalls offer more accessible prices for local customers, mostly indigenous and mestizos. Figure 2 shows the distribution of bushmeat in the trifrontier area.

Fig. 2. Flows of bushmeat in the trifrontier region.

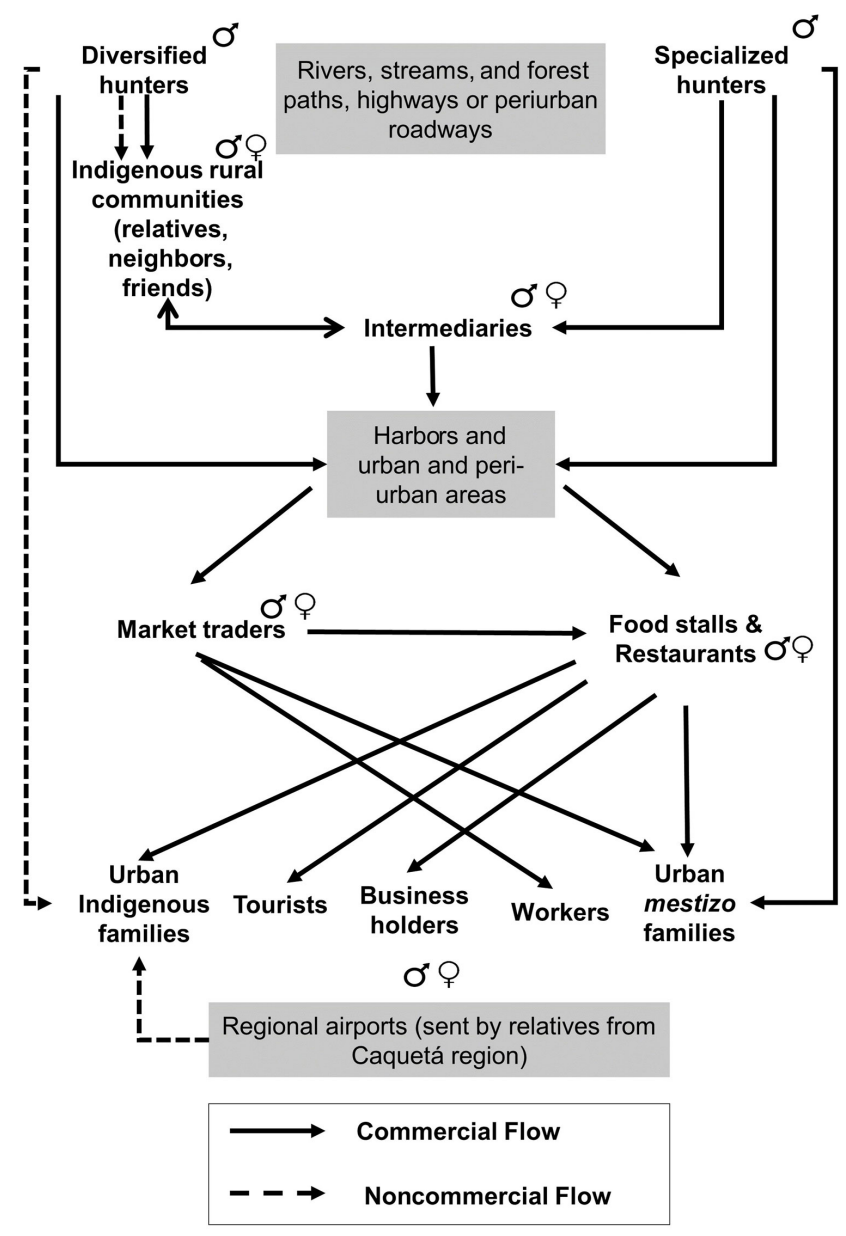




\section{Noncommercial flows of bushmeat}

\section{Bushmeat exchange networks}

The bushmeat exchange networks of the 3 families from our sample accounted for at least 92 people during the study period (Table 4). The number of people involved in exchanging bushmeat with the family, either receiving or giving, was highest for family 1 , who lived in the periurban area, and lowest for family 3, who lived in the urban area. We identified different types of relationships between the people that participated in the exchange networks. The strongest link was kinship, but there were also neighbors and friends, and even unknown persons that acted as intermediaries. The network consisted of people from the same or a different indigenous group and nonindigenous people with whom they shared friendship. Figure 3 shows the bushmeat exchange network of family 1 , illustrating the high variety of scenarios in which bushmeat exchanges took place. The most common way (several times a month) of receiving bushmeat was from gifts sent from the community of origin, mainly by plane, or from other indigenous families living in periurban areas. However, the transportation of bushmeat is subject to controls, fines, and confiscations from local authorities. The family also got bushmeat directly from the forest through hunting or from the shifting cultivation fields. Family members hunt in their shifting cultivation plot to reduce conflicts with crop production. On their way back from the shifting cultivation plot, they sometimes come across other neighbors and exchange bushmeat with other agricultural products or give bushmeat as a gift. The family distributes bushmeat to tourists when a member of the household acts as a tourist guide and to other indigenous households, either by inviting them for a meal at home or sharing a piece of the animal when coming back from the shifting cultivation fields or from the forest.

Fig. 3. Bushmeat exchange network of family 1.

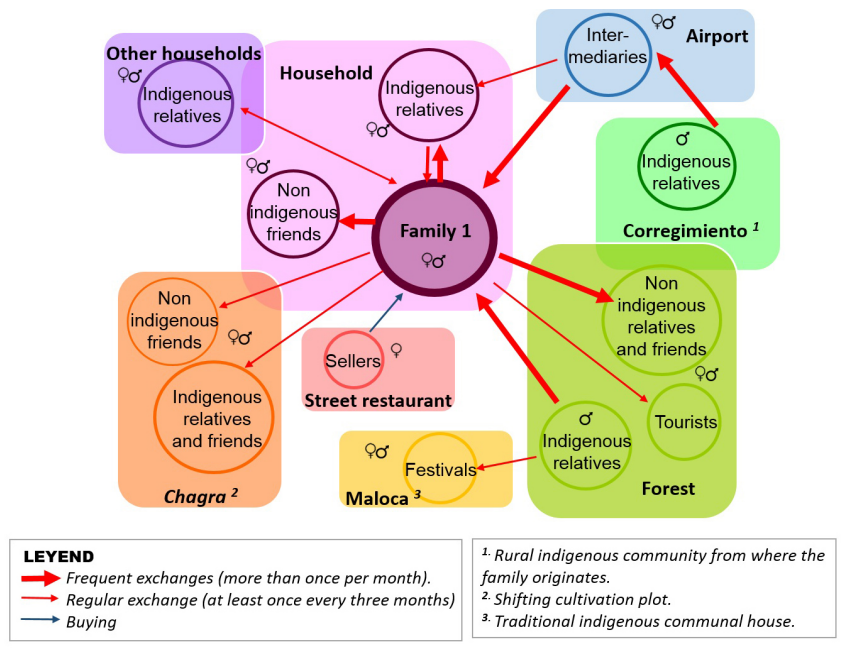

Motivations for exchanging bushmeat within social networks We identified two main motivations for exchanging bushmeat from rural to urban areas, particularly among indigenous families: immediate exchange and long-term exchange. In the case of immediate exchange, bushmeat is given or received at the same time as any other product or service. The mingas ${ }^{[1]}$ are an example of this: bushmeat may be offered in return for the work that participants provide in the shifting cultivation field (or chagra). In the case of long-term exchange, bushmeat is exchanged based on reciprocity logic very rooted among indigenous groups. Families share bushmeat with visitors or neighbors during meals to stimulate social interaction and demonstrate abundance. Food and bushmeat in particular are shared as a way of maintaining social networks that represent safety nets in case of specific needs, such as sending a child to school, medical care, and so forth. Bushmeat is also sent to urban areas for the preparation of the traditional dance rituals or festivals celebrated in the urban and periurban traditional communal houses (or malocas). These ethnic festivals center on community and family, evoking positive emotions. The consumption of particular and specific festival foods, such as bushmeat, is a way for urban indigenous groups to express their ethnic identity, promote family togetherness, and even deal with the stressors of adapting to a new culture.

Table 4. Estimation of the number of people participating in the bushmeat networks of the three families.

\begin{tabular}{|c|c|c|c|c|c|c|c|}
\hline \multirow[t]{2}{*}{ Family } & \multicolumn{2}{|c|}{$\begin{array}{l}\text { People in the } \\
\text { household }\end{array}$} & \multicolumn{2}{|c|}{$\begin{array}{l}\text { People in the } \\
\text { Network }\end{array}$} & \multicolumn{3}{|c|}{$\begin{array}{c}\text { Total number of people } \\
\text { exchanging bushmeat } \\
\text { within each family }\end{array}$} \\
\hline & Female & Male & Female & Male & Female & Male & $\begin{array}{l}\text { Total } \\
\text { both }\end{array}$ \\
\hline 1 & 5 & 9 & 15 & 11 & 20 & 20 & 40 \\
\hline 2 & 1 & 4 & 15 & 13 & 16 & 17 & 33 \\
\hline \multirow[t]{2}{*}{3} & 5 & 2 & 8 & 4 & 13 & 6 & 19 \\
\hline & & & & & \multicolumn{2}{|c|}{ Total } & 92 \\
\hline
\end{tabular}

\section{Cultural importance of noncommercial flows of bushmeat}

Although bushmeat is no longer consumed as a daily meal among urban and periurban indigenous families in Leticia, it constitutes what could be called a "festival food." Ethnic festival food refers to food that expresses attitudes, values, behaviors, cultural beliefs, traditions or heritage, religion, or national origin for native or ethnic groups. Although many factors influence food choice, such as convenience, affordability, and taste, for racial/ethnic minority groups food choice is an important means of relating to their ethnic background. The originality of our results is that they highlight the continued role that traditional foods may have, even in modern and highly transformed indigenous cultures. Typical traditional food items, such as bushmeat, have not completely disappeared from modern indigenous nutrition patterns in Leticia. Like many wild plants, bushmeat is part of the intangible cultural heritage of local populations and can be related to cultural identity. In Leticia, bushmeat is consumed at home on occasion, as well as during traditional festivities. Bushmeat is received and accepted with satisfaction by all participants in the meals and contributes to collective happiness. Food preferences and habits are formed in large part through childhood experiences and actually persist throughout the course of an individual's life, helping to maintain memories and strengthen connections with their traditional origins, their territory, and with associated resources. 


\section{DISCUSSION}

Our study describes the main characteristics of bushmeat flows that allow urban bushmeat consumption in the trifrontier towns. Bushmeat trade occurs under an organized but invisible trade chain, involving diversified and specialized hunters, market sellers, restaurants, and street food stalls. The structure of the bushmeat trade chain is very similar to what is observed in the Congo Basin (Lescuyer and Essoungou 2013) and West Africa (Cowlishaw et al. 2004), particularly concerning the type of stakeholders involved. However, there a number of differences in terms of gender, degree of specialization of the stakeholders, and extent of the trade routes. In the trifrontier region, both women and men are involved as market traders, whereas in Central Africa, only women are involved in bushmeat trade. In our study site, market traders combine the sale of bushmeat with other activities (e.g. sale of fish or clothing), whereas in Central Africa, most bushmeat traders specialize in bushmeat. Also important is the fact that in our study site, no bushmeat is sent to consumers outside the boundaries of the trifrontier, highlighting the absence of bushmeat trafficking to larger towns or to the capital cities outside the region, as is observed in Central Africa.

The bushmeat commodity chain contributes to local livelihoods in the region by providing direct income to 195 stakeholders in different ways. For diversified hunters, bushmeat complements a diverse panel of livelihood activities. However, as is also observed in African bushmeat trade chains (Okouyi 2006), some hunters specialize in commercial hunting and rely solely on hunting as their source of income. The level of law enforcement does not prevent the trade from occurring, but has implications for the structure and functioning of the trade chain. Because of the level of risk in getting involved in the ilegal bushmeat trade, the trade chain follows a "funnel" shape, with several hunters providing bushmeat to a very limited number of market traders in each town. Market traders need to be well connected to providers, consumers, and local authorities to avoid confiscations and to distribute quickly. As a result, the number of market traders involved is low and stable over time, each of them trading about 14 tons of bushmeat yearly, based on the total amount traded of 473 tons per year (see van Vliet et al. 2014). Transportation occurs in early hours before daylight. Hunting and trading are reliant on new technologies: hunting occurs using modern ways of transportation (motor boats, motorbikes), conservation (frozen meat), and communication (cell phones used as a way to rapidly communicate with clients). These characteristics of modern hunting and trade patterns have also been observed for periurban hunters in the Caatinga, Brazil (de Medeiros 2014), as a way to adapt to illegality.

The main clients of bushmeat markets and restaurants are nonindigenous people who can afford luxury meats (bushmeat is four times more expensive than industrial chicken, or as expensive as beef). However, bushmeat consumption is also common among indigenous people, who do not access bushmeat through the market but rather directly from the forest or through their tight rural-urban social networks. Our results highlight the fact that bushmeat is not consumed as a daily meal among urban and periurban indigenous families, but constitutes what could be called a festival food, understood as a food choice that may be related to identifying with their ethnic background (Chapman et al.2011) or as a comfort food consumed in positive social contexts, resulting in a positive association between the food and emotional well-being (Stein 2008). As such, bushmeat sharing is embedded in the logic of reciprocity and constitutes a sort of "insurance" or a safety net.

Our results have a number of important implications for policy. First, our study highlights the need to consider the existence of transborder trade in Convention on International Trade in Endangered Species of Wild Fauna and Flora (CITES) regulations, taking into account the particularities of border areas that share similar cultures and socioeconomic charateristics. The impacts of the application of CITES in such contexts would require a proper evaluation of its effects on local livelihoods and the identification of mitigation measures as indicated by resolution 16.6 from CITES (http://www.cites.org/res/16/16-06. php), where it is explicitly recognized that national governments should evaluate the impacts of CITES lists on the livelihoods of local communities, as well as create opportunities that provide sustainable incomes that enhance conservation and sustainable use.

Second, our understanding of the trade chain in the trifrontier region highlights the key role that traders play in the commodity chain and the need to consider their motivations when seeking bottom-up solutions to the unsustainable trade of bushmeat. Most mitigating measures have either targeted the hunters or the final consumers, but because of the illegality of the bushmeat trade, no incitative measures are taken at the level of market traders. These stakeholders are stable in time and difficult to replace, given their level of familiarity to the rest of the network, including local authorities. Because of their limited number (34 in the trifrontier towns) compared with hunters and consumers, actions could efficiently target the main stakeholders of the trade, almost with personalized incentives to engage in a sustainable business.

Finally, our results highlight the need to discuss the notion of "subsistence use" in this modern context of exchange flows among mobile and multisited indigenous households in the Amazon. Indeed, bushmeat consumption among urban indigenous families contributes to subsistence and follows the definition provided by legal frameworks, except for the place of consumption: not the rural community where bushmeat was hunted but rather a urban area. The possibility of explicitly expanding the definition of subsistence use to urban contexts needs further consideration to clearly distinguish between subsistence and commercial use in the implementation of law enforcement activities. Currently, indigenous families are subject to controls and confiscations if they transport bushmeat in urban areas or in the airport, and these enforcement activities could be undermining local subsistence rights. The speciality of current livelihoods in the Amazon calls for a redefinition of subsistence. Our results also suggest that the scientific and practitioner community should explore hunting systems that consider urban demand while managing for sustainability, rather than only considering the possibility of local subsistence use.

\footnotetext{
${ }^{[1]} \mathrm{A}$ minga is a communal event in which members of the village offer food in return for help from the community to build a house or work in agricultural fields.
} 
Responses to this article can be read online at: http://www.ecologyandsociety.org/issues/responses. php/7782

\section{Acknowledgments:}

We would like to thank all the stakeholders and families that agreed to participate in this research. This work would not be possible without the support and encouragement of Fernando Trujillo and Brigitte Baptiste. We are grateful to USAID and UKAID for supporting this work. Finally, this review study was conducted as part of the Bushmeat Research Initiative and the Program on Forest, Tree and Agroforestry that is conducted by a consortium composed of CIAT, ICRAT, Bioversity, and CIRAD, and is led by CIFOR.

\section{LITERATURE CITED}

Alexiades N., 2009. The cultural and economic globalisation of traditional environmental knowledge systems. Pages 68-98 in $\mathrm{S}$. Heckler, editor. Landscape, process and power: re-evaluating traditional environmental knowledge. Berghahn, Oxford, UK.

Baía, P. C., Jr., D. A. Guimarães, and Y. Le Pendu. 2010. Nonlegalized commerce in game meat in the Brazilian Amazon: a case study. Revista de Diología Tropical 58(3):1079-1088.

Bernal, R. J., and E. M. T. Mainbourg. 2009. Indios urbanos: processo de reconformação das identi-dades étnicas indígenas em Manaus. Editora da Universidade Federal do Amazonas, Manaus, Brazil.

Bodmer R. E., J. F. Eisenberg, and K. H. Redford. 1997. Hunting and the likelihood of extinction of Amazonian mammals. Conservation Biology 11(2):460-466. http://dx.doi.org/10.1046/ j.1523-1739.1997.96022.x

Bodmer, R. E., and E. P. Lozano. 2001. Rural development and sustainable wildlife use in Peru. Conservation Biology 15 (4):1163-1170. http://dx.doi.org/10.1046/j.1523-1739.2001.0150041163. $\underline{\mathrm{x}}$.

Bodmer, R. E., E. P. Lozano, and T. G. Fang. 2004. Economic analysis of wildlife use in the Peruvian Amazon. Pages 191-207 in K. M. Silvins, R. Bodmer, and J. M. V. Fragoso, editors. People and nature: wildlife conservation in South and Central America. Columbia University Press, New York, New York, USA.

Chapman, G. E., S. Ristovski-Slijepcevic, and B. L. Beagan. 2011. Meanings of food, eating and health in Punjabi families living in Vancouver, Canada. Health Education Journal 70(1):102-12. http://dx.doi.org/10.1177/0017896910373031

Convention on Biological Diversity (CBD). 2011. Livelihood alternatives for the unsustainable use of bushmeat. Report prepared for the CBD Bushmeat Liaison Group. Technical Series No. 60. Secretariat of the Convention on Biological Diversity, Montreal, Quebec, Canada.

Cowlishaw, G., S. Mendelson, and M. Rowcliffe. 2004. The bushmeat commodity chain: patterns of trade and sustainability in a mature urban bushmeat market in West Africa. ODI Wildlife Policy Briefing No. 7. Overseas Development Institute, London, UK. [online] URL: http://www.odi.org/publications/2422- bushmeat-commodity-chain-trade-sustainability-mature-urban-marketwest-africa

Damania, R., E. J. Milner-Gulland, and D. J. Crookes. 2005. A bioeconomic analysis of bushmeat hunting. Proceedings of the Royal Society B 272(1560):259-266. http://dx.doi.org/10.1098/ $\underline{\text { rspb.2004.2945 }}$

de Medeiros, W. S. S. 2014. Atividades cinegéticas, usos locais e tradicionais da fauna por povos do semiárido paraibano (Bioma Caatinga). Universidade Federal da Paraíba Centro de Ciências Exatas e da Natureza (CCEN) Programa de Pós-Graduação em Ciências Biológicas (PPGCB). João Pessoa, Paraíba, Brasil.

Departamento Administrativo Nacional de Estadística (DANE). 2007. Censo general 2005. DANE, Bogotá, Columbia. [online] URL:http://www.dane.gov.co/index.php/poblacion-y-demografia/ censos.

Eloy, L., and C. Lasmar. 2012. Urbanisation and transformation of indigenous resource management: the case of Upper Rio Negro (Brazil). International Journal of Sustainable Society 4 (4):372-388. http://dx.doi.org/10.1504/ijssoc.2012.049407

Fragoso, J. M. V., K. M. Silvius, and M. Villa-Lobos. 2000. Wildlife management at the Rio das Mortes Xavante Reserve, $M Y$, Brazil: integrating indigenous culture and scientific method for conservation. World Wildlife Fund-Brazil, Brasilia, Brazil.

Guber, R. 2001. La etnografía. Método, campo y reflexividad. Grupo Editorial Norma, Bogotá, Columbia.

Guedes, G., S. Costa, and E. Brondízio. 2009. Revisiting the hierarchy of urban areas in the Brazilian Amazon: a multilevel approach. Population and Environment 30(4-5):159-192. ttp://dx. doi.org/10.1007/s11111-009-0083-3

Hill, K., G. McMillan, and R. Fariña. 2003. Hunting-related changes in game encounter rates from 1994 to 2001 in the Mbaracayu Reserve, Paraguay. Conservation Biology 17 (5):1312-1323. http://dx.doi.org//10.1046/j.1523-1739.2003.01135. $\underline{x}$

Instituto Brasileiro de Geografia e Estatística (IBGE). 2010. Joint statistical publication by BRIC countries. Brazil, Russia, India, China. Gerência de Editoração/Centro de Documentação e Disseminação de Informações (CDDI/IBGE), Rio de Janeiro, Brazil.

Instituto Nacional de Estadística e Informática (INEI). 2008. Perú: crecimiento y distribución de la población, 2007. Instituto Brasileiro de Geografia e Estatística. Fondo de población de las Naciones Unidas, Lima, Perú.

Instituto Nacional de Estadística e Informática (INEI). 2010. Perú: análisis Etnosociodemográfico de las Comunidades Nativas de la Amazonía, 1993 y 2007. Dirección Técnica de Demografía e Indicadores Sociales. Fondo de población de las Naciones Unidas, Lima, Perú.

Instituto Nacional de Estadística e Informática (INEI). 2011. Perú: anuario de estadísticas ambientales - 2011. Fondo de población de las Naciones Unidas, Lima, Perú. [online] URL: http://www.siar.regioncusco.gob.pe/admDocumento.php?accion= bajar\&docadjunto $=3027$ 
Lescuyer, G., and N. J. Essoungou. 2013. Gestion forestière multiusages en Afrique centrale: perceptions, mises en uvre et évolutions. Bois et Forets des Tropiques 67(315):29-37.

Levi, T., G. H. Shepard, Jr., J. Ohl-Schacherer, C. A. Peres, and D. W. Yu. 2009. Modelling the long-term sustainability of indigenous hunting in Manu National Park, Peru: landscapescale management implications for Amazonia. Journal of Applied Ecology 48(4):804-814. http://dx.doi.org/10.1111/j.1365-2664.2009.01661. $\underline{\mathrm{x}}$

Mainbourg, E. M. T., M. I. Araújo, and I. C. de Almeida. 2002. Populações indígenas da cidade de Manaus inserção na cidade e ligaçao com a cultura. Paper presented at the XIII Encontro Nacional de Estudos Populacionais of the Associação Brasileira de Estudos Populacionais (ABEP). Minas Gerais, Brazil.

Marshall, C., and G. B. Rossman. 2011. Designing qualitative research. Sage, Thousand Oaks, California, USA.

Maxwell, J. A. 2008. Designing a qualitative study. Pages 214-253 in L. Bickman, and D. J. Rog, editors. The handbook of applied social research methods. Second edition. Sage, Thousand Oaks, California, USA.

Nardoto, G. B., R. S. S. Murrieta, L. E. G. Prates, C. Adams, M. E. P. E. Garavello, T. Schor, A. de Moraes, F. D. Rinaldi, J. G. Gragnani, E. A. F. Moura, P. J. Duarte-Neto, and L. A. Martinelli. 2011. Frozen chicken for wild fish: nutritional transition in the Brazilian Amazon region determined by carbon and nitrogen stable isotope ratios in fingernails. American Journal of Human Biology 23:642-650. http://dx.doi.org/10.1002/ajhb.21192

Nasuti, S., L. Eloy, C. Raimbert, and F.-M. Le Tourneau. 2015. Can rural-urban household mobility indicate differences in resource management within Amazonian communities? Bulletin of Latin American Research 34:35-52. http://dx.doi.org/10.1111/ blar. 12147

Ojasti, J. 2000. Manejo de fauna neotropical. Instituto de Zoología Tropical, Caracas, Venezuela.

Okouyi, J. 2006. Savoirs locaux et outils modernes cynégétiques : développement de la filière commerciale de viande de brousse à Makokou (Gabon). Université of Orléan, Orléan, France.

Ostrom, E. 2007. Sustainable social-ecological systems: an impossibility? Paper presented at the 2007 Annual Meeting of the American Association for the Advancement of Science, Science and Technology for Sustainable Well-Being, 15-19 February (San Francisco, California, USA). http://dx.doi.org/10.2139/ssrn.997834

Parry, L., J. Barlow, and H. Pereira. 2014. Wildlife harvest and consumption in Amazonia's urbanized wilderness. Conservation Letters 7(6):565-574. http://dx.doi.org/10.1111/conl.12151

Parry, L., B. Day, S. Amaral, and C. A. Peres. 2010. Drivers of rural exodus from Amazonian headwaters. Population and Environment 32:137-176. http://dx.doi.org/10.1007/s11111-010-0127-8

Peluso, D. M., and M. Alexiades. 2005. Urban ethnogenesis begins at home: the making of self and place amidst Amazonia's environmental economy. Traditional Dwellings and Settlements Review 16(2):1-10.

Pinedo-Vasquez, M., and C. Padoch. 2009. Urban, rural and inbetween: multi-sited households, mobility and resource management in the Amazon floodplain. Pages 86-96 in M. N. Alexiades, editor. Mobility and migration in indigenous Amazonia: contemporary ethnoecological perspectives. Berghahn, Oxford, UK.

Riaño, E. 2003. Organizando su espacio, construyendo su territorio. Transformaciones de los asentamientos Ticuna en la ribera del Amazonas colombiano. Unibiblos, Bogotá, Colombia.

Rushton, J., R. Viscarra, C. Viscarra, F. Basset, R. Baptista and D. Brown. 2005. How important is bushmeat consumption in South America: now and in the future? ODI Wildlife Policy Briefing No. 1. Overseas Development Institute, London, UK. [online] URL: http://www.odi.org.uk/resources/download/2418.pdf

Sampaio, P. A. M. 2003. Comércio ilegal de carne de animais silvestres em quatro feiras livres do estuario amazônico, Estado do Pará-Brasil. Trabalho de Conclusão de Curso. Universidade Federal do Pará, Centro de Ciências Biológicas. Belém, Pará, Brazil.

Sills, E., P. Shanley, F. Paumgarten, J. de Beer, and A. Pierce. 2011. Evolving perspectives on non-timber forest products. Pages 23-51 in S. Shackelton, C. Shackelton, and P. Shanley, editors. Nontimber forest products in the global context. Springer-Verlag, Berlin, Germany. http://dx.doi.org/10.1007/978-3-642-17983-9_2

Silvius, K. M., R. E. Bodmer, and J. M. V. Fragoso, editors. 2004. People in nature: wildlife conservation in South and Central America. Columbia University Press, New York, New York, USA.

Sirén A. H. 2012. Festival hunting by the Kichwa people in the Ecuadorean Amazon. Journal of Ethnobiology 32(1):30-50. http:// dx.doi.org/10.2993/0278-0771-32.1.30

Sirén, A., P. Hämback, and J. Machoa. 2004. Including spatial heterogeneity and animal dispersal when evaluating hunting: a model analysis and an empirical assessment in an Amazonian community. Conservation Biology 18:1315-1329. http://dx.doi. org/10.1111/j.1523-1739.2004.00024.x

Stein, K. 2008. Contemporary comfort foods: bringing back old favorites. Journal of the Academy of Nutrition and Dietetics 108 (3):412-414. http://dx.doi.org/10.1016/j.jada.2008.01.032

Sobreiro, T. 2015. Urban-rural livelihoods, fishing conflicts and indigenous movements in the Middle Rio Negro Region of the Brazilian Amazon. Bulletin of Latin American Research 34 (1):53-69. http://dx.doi.org/10.1111/blar.12259

Suárez-Mutis, M, C. M. M. Cárdenas, L. del Pilar Pérez Reyes, and P. C. Peiter. 2010. Interacciones transfronterizas y salud en la frontera Brasil-Colombia-Perú. Mundo Amazónico 1:243-266. http://dx.doi.org/10.5113/ma.1.10268

van Vliet, N., M. P. Quiceno-Mesa, D. Cruz-Antia, C. Morsello, C. Adams, F. Mori, B. Yagüe, S. Hernández, T. Bonilla, L. Tellez, L. Neves de Aquino, J. Moreno, T. Schor, M. P. de Oliveira, E. Haiden, F. Trujillo, and R. Nasi. 2014. Bushmeat in the tri-frontier region of Brazil, Peru and Colombia: demise or persistence? CIFOR Occasional PaperZ No. 118. Center for International Forestry Research (CIFOR), Bogor, Indonesia. http://dx.doi. org/10.17528/cifor/005363 
Wildlife Conservation Society (WCS). 2007. El tráfico de carne silvestre en el Parque Nacional Yasuní: caracterización de un mercado creciente en la Amazonia Norte del Ecuador. Programa Ecuador. Boletín No. 2. WCS, Quito, Ecuador. [online] URL: http://s3.amazonaws.com/WCSResources/file 20110823 035823_ecu_pub_ProgramaEcuadorBoletin2_2007_oAuB.pdf

Zarate, C. 2008. Fronteras en la globalización: localidad, biodiversidad y comercio en la Amazonia. Volume 1. Observatorio Andino. Universidad Javeriana, Bogotá, Colombia. ISBN: 978-958-98301-1-6. 
Appendix 1

Interview at level of hunters (Spanish)

$\begin{array}{ll}\text { Nombre del cazador } & \text { Fecha } \\ \text { ¿Dónde vive? } & \text { Edad }\end{array}$

$\begin{array}{ll}\text { Nombre del cazador } & \text { Fecha } \\ \text { ¿Dónde vive? } & \text { Edad }\end{array}$

¿Dónde vive?

Edad

¿Hace cuánto llegó a la región?

TÉCNICAS Y PRÁCTICAS DE CAPTURA

Qué especies caza:

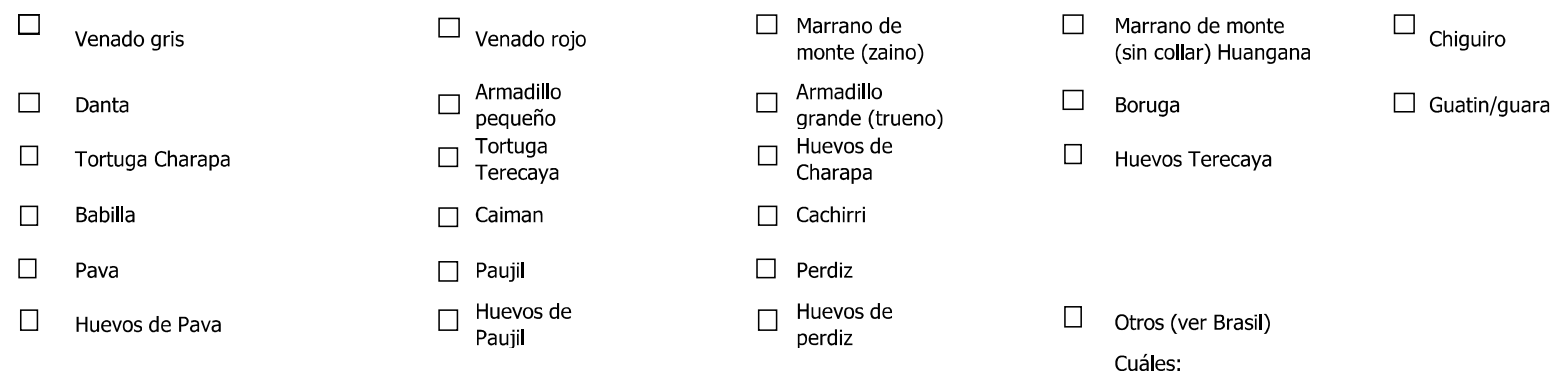

Hace cuanto es cazador? Cómo aprendió a cazar?

Cómo captura los animales

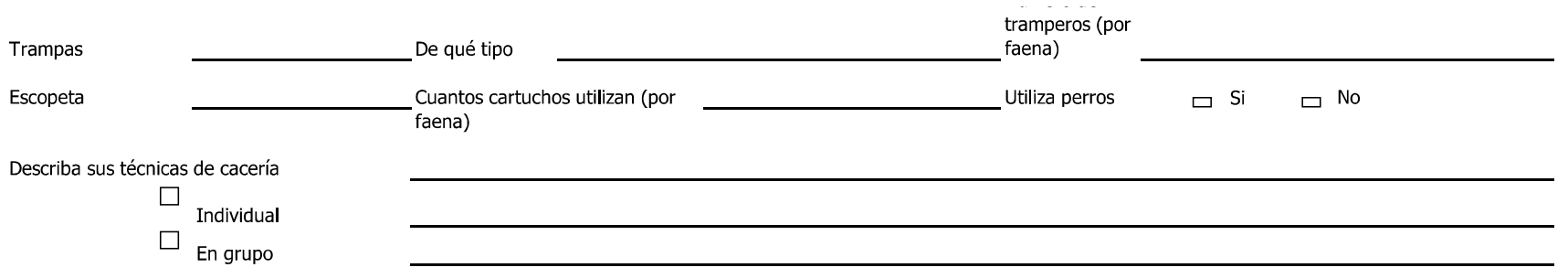

Por faena de caza, cuantas especies caza:

Cuántas veces sale de caceria en un mes?

Cuántas horas/días invierte por faena?

Temporadas y lugares de captura

Especies capturadas en la ultima semana

Mamíferos terrestres

Dónde:

Mamíferos arboricolas

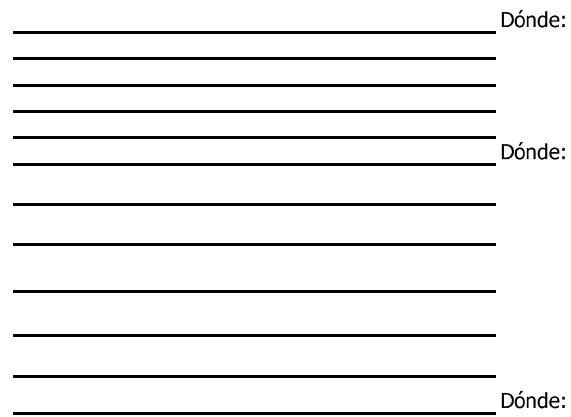




\section{Especies capturadas el ultimo mes}

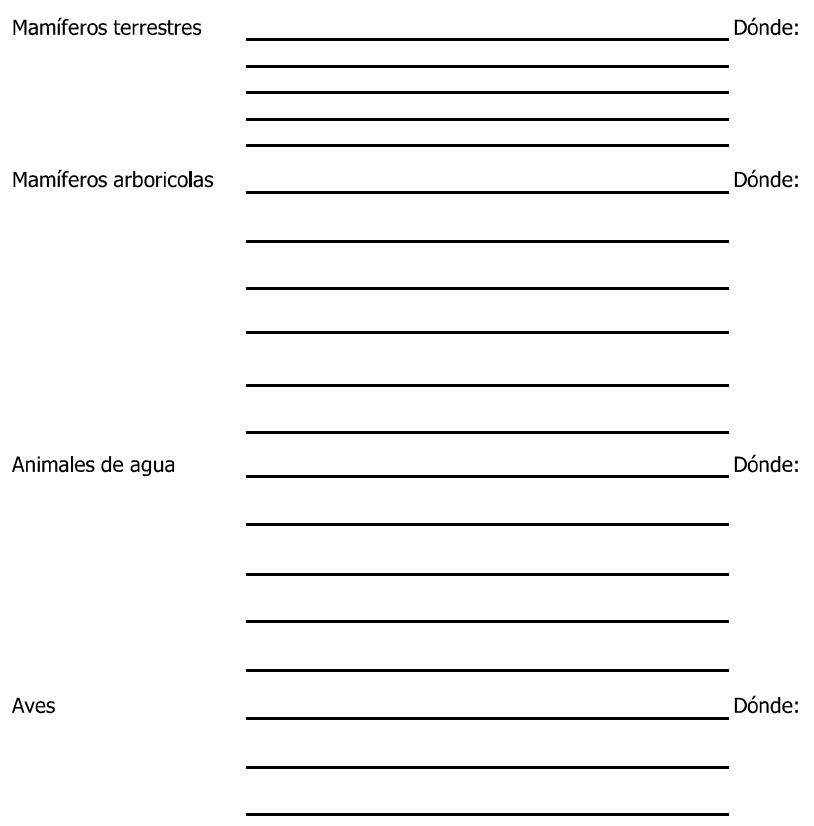

Especies capturadas en los ultimos tres meses

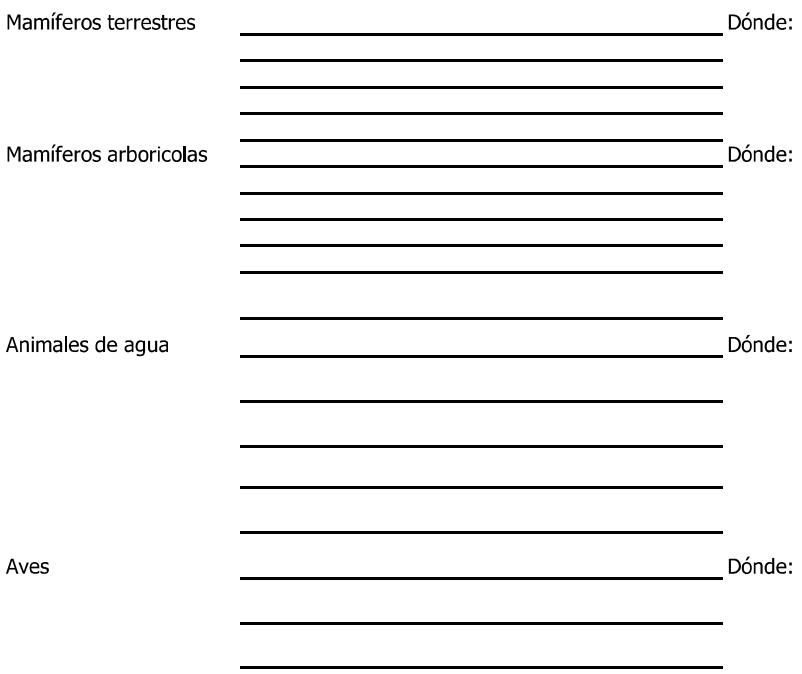


Nombre de la zona donde prefiere cazar:

Cómo llega? (medio de transporte):

A quién pertece ese territorio?:

Cómo conoció esos lugares? Tiene algun conocido en el lugar?:

Cuándo se captura mas especies:

Aguas altas

Aguas bajas

Antes había más animales?

Por qué ahora hay menos, mas?

Qué es lo que le gusta de ir de cacería?

Qué es lo que no le gusta de ir de cacería?

Comparte con otros el producto de la caza:

$\square$ Si No

Con Quién
$\square \quad$ Familiar

$\square \quad$ Amigo

$\square \quad$ Jefe
Tipo de bosque donde caza

Cuántas horas dura para llegar?

Explique

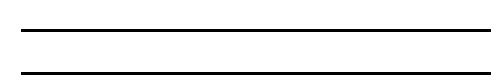

Otra persona:

\section{Motivo de la caza:}

Auto consumo

Pedido cliente

Captura oportunista

Le gusta la actividad

Otra $\square$

$\square \quad$ cuál?

Cuanto del producto de la caza se destina a:

$\begin{array}{ll}\text { Auto-consumo: } & \text { una parte: } \\ \text { Venta : } & \text { una parte: }\end{array}$

Cuando vende la carne de monte, en que utiliza el dinero obtenido y quien lo utiliza?

\begin{tabular}{llll}
$\square$ & Alimentos Cuales: & \\
\hline & & \\
& & \\
$\square$ & Cigarrilos y alcohol & quien compra \\
$\square$ & Productos de higiene (jabon...) & quien compra \\
$\square$ & Gasolina & quien compra \\
$\square$ & Bebidas & quien compra \\
$\square$ & Otros & quien compra
\end{tabular}


A quién vende lo que caza:

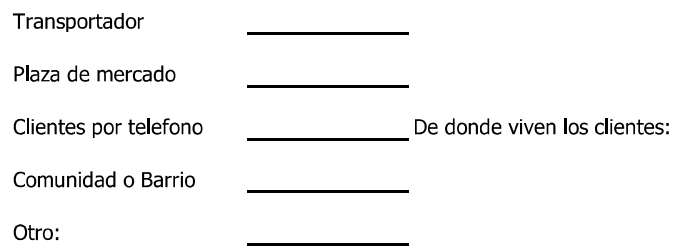

Quien vende lo que se caza :

El mismo cazado

La esposa

Otro miembro de la comundiad

Costos de la faena de caza

$\begin{array}{ll}\text { Gasolina } & \text { precio al galon } \\ \text { Material de caza 1 } & \text { costo } \\ \text { Material de caza 2 } & \text { costo } \\ \text { Material de caza 3 } & \text { costo } \\ \text { Otros } & \text { costo }\end{array}$

Cuanto compra por mes?

Cuanto compra por mes?

Cuanto compra por mes?

Cuanto compra por mes?

Cuanto compra por mes?

\section{Recibe subsidio para la caza:}

Quien paga el subsidio: $\square \mathrm{Si}$

De cuanto es?

en donde compra?

en donde compra?

en donde compra?

en donde compra?

en donde compra?

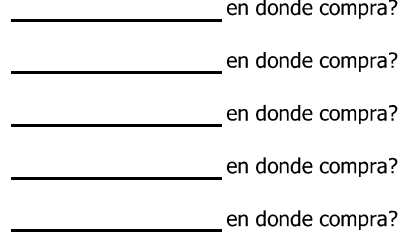

De donde viene

\section{CONTROL Y DECOMISOS}

Ha sido controlado por transporte o comercio de carne de monte?

Quien lo ha controlado?
$\square$
Policia ambiental-Sijin
Armada
$\square \quad$ Guardia costera

Con que frecuencia piensa usted que ha sido controlado en los ultimos tres meses?:

En los últimos tres meses ha sido Penalizado?

Ha sido penalizado por el transporte o comercio de carne de monte?

Como ha sido penalizado?

$\begin{array}{lll}\square & \text { Multa } & \text { Cuanto pago? } \\ \square & \text { Cárcel } & \text { Cuanto tiempo estuvo en la carcel? } \\ \square & \text { Decomiso } \quad \text { Cuantos kilos le quitaron? } \\ \square & \text { Pago de contrapia? } \\ \square & \text { Trabajo comuniti Cuantos dias? } \\ \square & \text { otro } & \text { Explique }\end{array}$

Cuántos controles hacen por mes?

\section{CARACTERISTICAS DE AUTOCONSUMO - Chagras}

Distancia de la casa a la chagra?

Que cultiva en la chagra?

Lo que cultiva en la chagra es destinado

$\square \quad$ Consumo familiar 


\section{OTRAS ACTIVIDADES PRODUCTIVAS}

A que otras actividades productivas se dedica? (productivas= que le produzca ingresos)

$\square \quad$ Venta productos agricolas

$\square$

Venta de artesanias

$\square \quad$ Venta de productos de la pesca

$\square$ Empleo fijo

$\square$ Empleo temporal o jornalero

$\square \quad$ Comercio/Almacen

$\square \quad$ otro
Cuanto vende al mes?

Cuanto vende al mes?

Cuanto vende al mes?

Cuantos dias trabaja al mes?

Cuantos dias trabaja al mes?

Cuanto vende al mes?

Cuanto vende al mes?
Cuanto gana al mes?

Cuanto gana al mes?

Cuanto gana al mes?

Cuanto gana al mes?

Cuanto gana al mes?

Cuanto gana al mes?

Cuanto gana al mes?

\section{CARACTERISTICAS SOCIOECONOMICAS}

Lugar de la vivienda

Tiempo que ha vivido ahí

Casado:

$\square \mathrm{Si}$

$\square$ No

No hijos:

Cuántas familias viven en su comunidad

Cuántas familias cree usted que cazan y venden carne de monte

Cuántas personas viven en su casa

En la siguiente tabla ponga los datos de las personas que viven con usted:

\begin{tabular}{|l|l|l|l|l|l|}
\hline Nombre & Edad & Parentesco & Sexo & Educación & Ocupación** \\
\hline & & & & & \\
\hline & & & & & \\
\hline & & & & & \\
\hline & & & & & \\
\hline & & & & & \\
\hline
\end{tabular}

** categorias: pesca, artesanías, jornal, comercial, industria, caza, industria, estudiante, hogar, otro 
¿Dónde vive?

¿Dónde nació?

¿Hace cuánto llegó a la región?

\section{PLATOS, PREFERENCIAS Y PRECIOS}

Qué tipo de carne vende

$$
\begin{array}{ll}
\square & \text { Carne de Pollo } \\
\square & \text { Carne de Res } \\
\square & \text { Pescado } \\
\square & \text { Carne de Monte }
\end{array}
$$

De qué especies viene la carne de monte

$\begin{array}{llllll}\square \text { Venado gris } & \square & \text { Venado rojo } & \square & \text { Marrano de monte (zaino) } \\ \square \text { Danta } & \square & \text { Armadillo pequeño } & \square & \text { Armadillo grande (trueno) } & \text { Huevos de Paujil } \\ \square \text { Pava } & \square & \text { Paujil } & \square & \text { Huevos de Pava } & \square \\ \square \text { Tortuga Charapa } & \square & \text { Tortuga Terecaya } & \square & \text { Huevos de Charapa } & \text { Huevos Terecaya } \\ \square \text { Babilla } & \square & \text { Caiman } & \square & \text { Marrano de monte (sin collar) } & \\ \square \text { Boruga } & \square & \text { Otros } & & & \\ & & \text { Cuáles: } & & \end{array}$

\section{Cómo compra Fresca

$$
\begin{gathered}
\text { Salada } \\
\text { Ahumada }
\end{gathered}
$$$$
\text { Anumada }
$$
Cuâles:

Quién le provee esos productos

Carne de Pollo

Carne de Res

Pescado

Carne de Monte

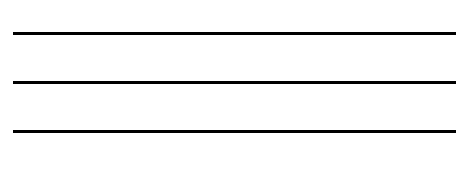

Que porcentaje de carne de monte vende en relacion con el resto de carnes?

Un tercio

La mitad

La totalidad

Cuál es la carne mas preciado por los clientes?

Carne de Pollo

Carne de Res

Pescado

Carne de Monte

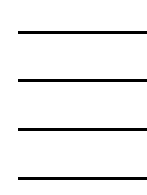

grupo etnico

grupo etnico

grupo etnico

\begin{tabular}{|c|c|c|c|c|c|c|c|}
\hline $\begin{array}{l}\text { ¿Qué tipo de carne } \\
\text { vende? }\end{array}$ & $\begin{array}{c}\text { ¿Qué animales } \\
\text { vende? }\end{array}$ & $\begin{array}{l}\text { Precio de compra } \\
\text { por kilo }\end{array}$ & $\begin{array}{c}\text { kg comprados a la } \\
\text { semana }\end{array}$ & Total kgs comprados al mes & $\begin{array}{c}\text { ¿Cuántos clientes } \\
\text { compran cada } \\
\text { tipo de carne cada } \\
\text { dia? }\end{array}$ & $\begin{array}{l}\text { ¿Cuántos } \mathrm{kg} \text { de carne } \\
\text { compra cada cliente en } \\
\text { promedio cada dia? }\end{array}$ & $\begin{array}{l}\text { Precio de venta por } \\
\text { kilo }\end{array}$ \\
\hline & Venado & & & & & & \\
\hline & Zaino & & & & & & \\
\hline
\end{tabular}

grupo etnico

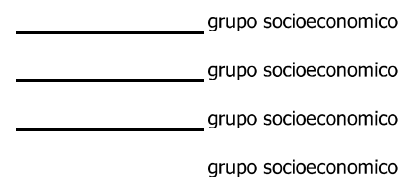

Por qué

ABASTECIMIENTO, CADENA DE MERCADO Y COSTOS 


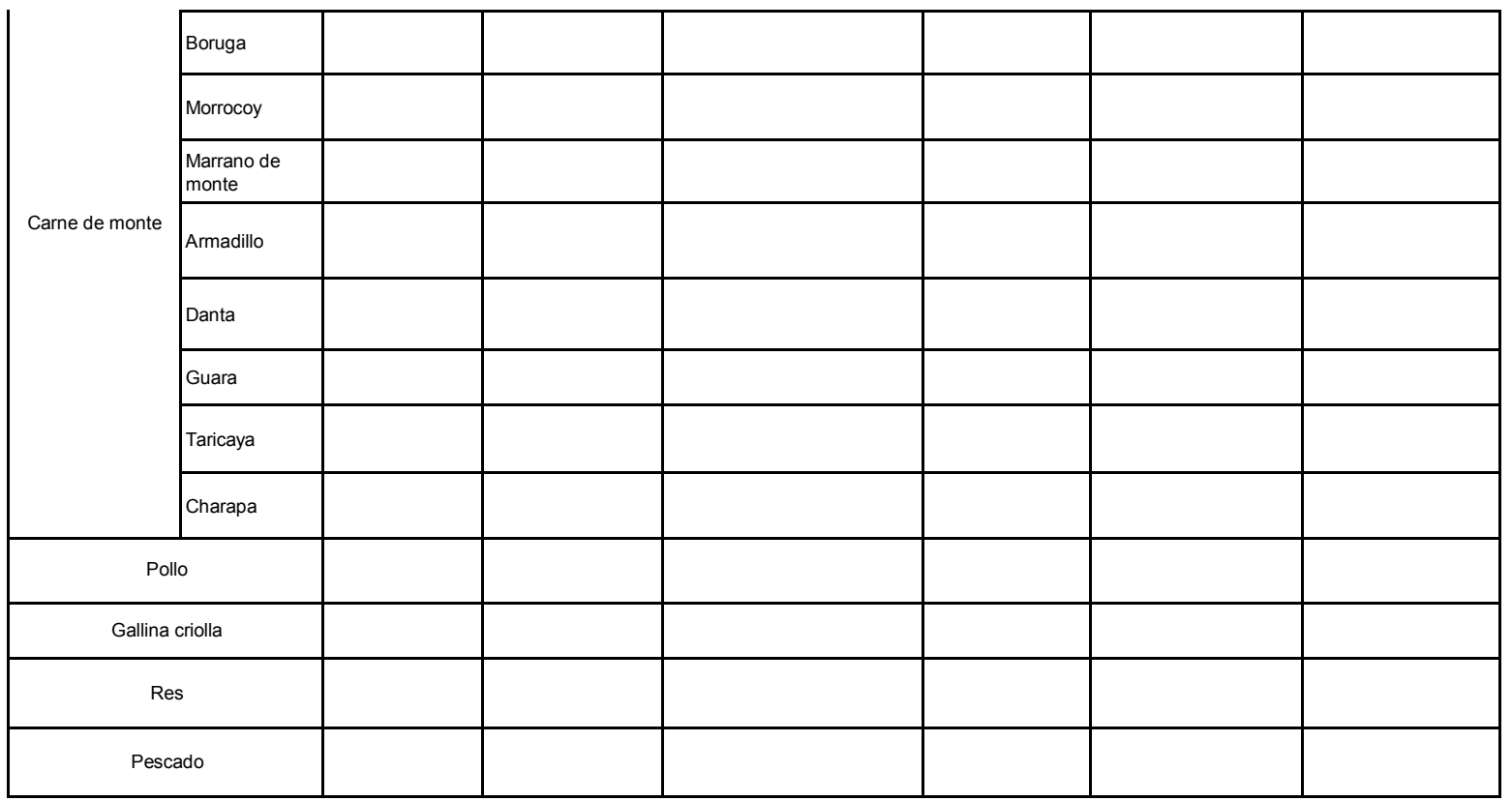

Cuántos días trabaja a la semana?

A qué hora abre?

A qué hora cierra?

Cuántos clientes tiene al día en total?

Gastos MENSUALES del negocio (nota: señalar unidad)

Agua

Luz

Arriendo del puesto

Gas

Hielo

Sal

Transporte

Salarios

\section{ESTACIONALIDAD PRECIOS}

Hay estacionalidad en los precios
Venta de carne de monte
$\square$ SI
$\square \quad$ No
Compra de carne de monte
$\square \mathrm{Si}$
$\square \quad$ No

Rango de precios por estacionalidad

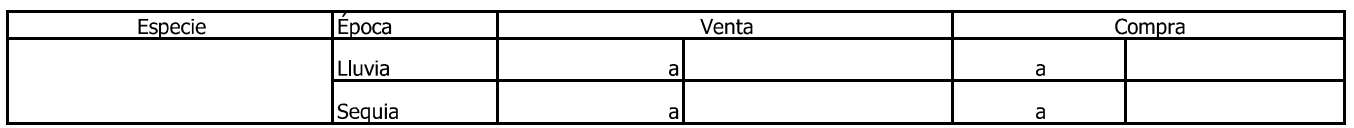

En qué época compran más carne de monte?

De que depende la demanda?

\section{CONTROL Y DECOMISOS}

Ha sido controlado por compra o venta de carne de monte?

$\square \quad$ Si $\quad \square$ No 
Con que frecuencia piensa usted que ha sido controlado:

Como ha sido penalizado?

$\begin{array}{lll}\square & \text { Multa } \quad \text { Cuanto pago? } \\ \square & \text { Cárcel } \quad \text { Cuanto tiempo estuvo en la carcel? } \\ \square & \text { Decomiso } \quad \text { Cuantos kilos le quitaron? } \\ \square & \text { Pago de contraparl Cuanto pago? } \\ \square & \text { Trabajo comunitar Cuantos dias? } \\ \square & \quad \text { Explique }\end{array}$

Cuántos controles hacen por mes?

\section{CARACTERISTICAS SOCIOECONOMICAS}

Lugar de la vivienda Tiempo que ha vivido ahí:

Casado:

$\square \mathrm{Si}$

$\square \quad$ No

No hijos:

Cuántas personas trabajancon usted?:

En la siguiente tabla ponga los datos de las personas que trabajan con usted:

\begin{tabular}{|l|l|l|l|l|l|}
\hline Nombre & Edad & Parentesco & Sexo & Educación & Ocupación** \\
\hline & & & & & \\
\hline & & & & & \\
\hline & & & & & \\
\hline
\end{tabular}

** categorias: pesca, artesanías, jornal, comercial, industria caza, industria, estudiante, hogar, otro 
Nombre del restaurante

Fecha

Propietario (o persona encuestada):

Edad

¿Dónde vive?

¿Dónde nació?

¿Hace cuánto llegó a la región?

PLATOS, PREFERENCIAS Y PRECIOS

Qué tipo de platos vende mas

$$
\begin{array}{ll}
\square & \text { Carne de Pollo } \\
\square & \text { Carne de Res } \\
\square & \text { Pescado } \\
\square & \text { Carne de Monte }
\end{array}
$$

De qué especies viene la carne de monte
$\square \quad$ Venado gris
$\square \quad$ Danta
$\square \quad$ Pava
$\square \quad$ Tortuga Charapa
$\square$ Babilla
$\square$ Boruga

$\square \quad$ Venado rojo

$\square \quad$ Paujl

$\square \quad$ Tortuga Terecaya

$\square \quad$ Caiman

$\square \quad$ Otros

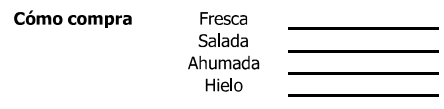

Quién le provee esos productos

Carne de Pollo

Carne de Res

Pescado

Carne de Monte

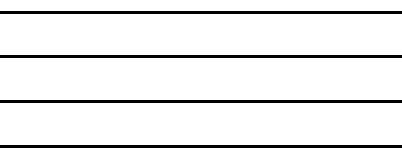

Que porcentaje de carne de monte vende en relacion con el resto de platos en el restaurante

Un tercio

$$
\square
$$

La mitad

$\square$

La totalidad

$\square$

Cuál es el plato mas preciado por los clientes

Carne de Pollo

Carne de Res

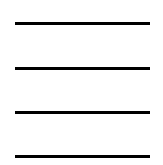

grupo etnico

Pescado

grupo etnico

Carne de Monte

grupo etnico

\begin{tabular}{|c|c|c|c|c|c|c|c|c|}
\hline $\begin{array}{l}\text { ¿Qué tipo de carne } \\
\text { vende? }\end{array}$ & $\begin{array}{c}\text { ¿Qué animales } \\
\text { vende? }\end{array}$ & $\begin{array}{c}\text { Precio de } \\
\text { compra por kilo }\end{array}$ & kg comprados al dia & Total kgs comprados al mes & $\begin{array}{c}\text { ¿Cuántos platos } \\
\text { se sacan por cada } \\
\text { kg de carne? }\end{array}$ & $\begin{array}{l}\text { ¿Cuántos clientes } \\
\text { compran cada tipo de } \\
\text { carne cada dia? }\end{array}$ & Precio plato & $\begin{array}{c}\text { ¿Cuántos } \\
\text { platos venden } \\
\text { por cada tipo } \\
\text { de carne cada } \\
\text { dia? } \\
\end{array}$ \\
\hline \multirow{7}{*}{ Carne de monte } & Venado & & & & & & & \\
\hline & Zaino & & & & & & & \\
\hline & Boruga & & & & & & & \\
\hline & Morrocoy & & & & & & & \\
\hline & \begin{tabular}{|l|} 
Marrano de \\
monte
\end{tabular} & & & & & & & \\
\hline & Armadillo & & & & & & & \\
\hline & Danta & & & & & & & \\
\hline
\end{tabular}

grupo etnico

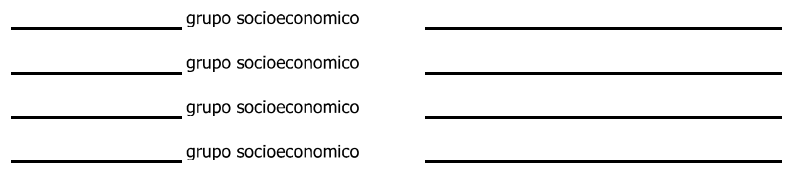

Por qué

ABASTECIMIENTO, CADENA DE MERCADO Y COSTOS 


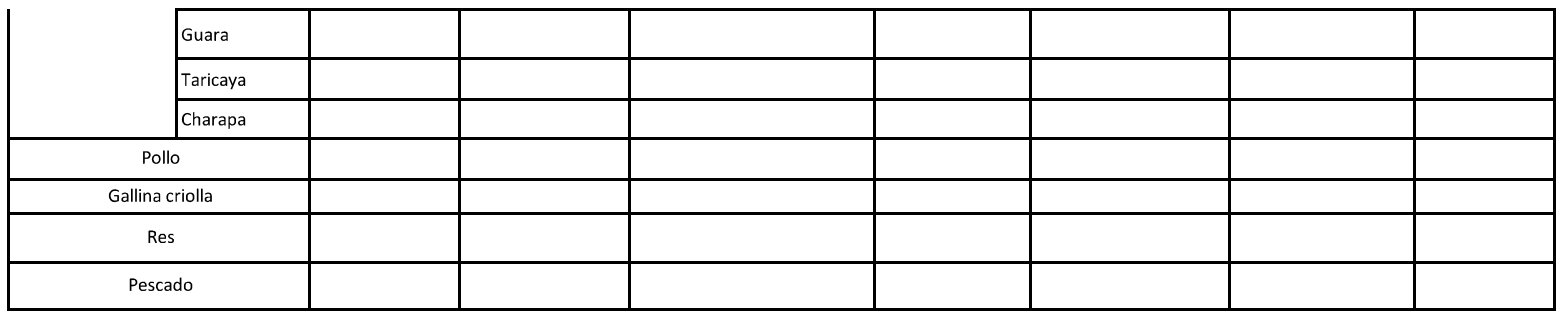

Cuánto dinero invierte DIARIAMENTE para comprar los demás alimentos que NO SEAN CARNES?

Cuántos días trabaja a la semana?

A qué hora abre el restaurante?

A qué hora cierra?

Cuántos clientes tiene al día en total?

Gastos MENSUALES del negocio (nota: señalar unidad)

Agua

Luz

Arriendo del puesto

Gas

Hielo

Sal

Transporte

Salarios

ESTACIONALIDAD PRECIOS

Hay estacionalidad en los precios
Venta de carne de monte
$\square$ SI
$\square \quad$ No
Compra de carne de monte
$\square \mathrm{Si}$
$\square \quad$ No

Rango de precios por estacionalidad

\begin{tabular}{|l|l|r|r|r|r|}
\hline Especie & Época & \multicolumn{2}{|c|}{ Venta } & \multicolumn{2}{|c|}{ Compra } \\
\hline & Lluvia & $a$ & & a & \\
\cline { 2 - 6 } & Sequia & a & a & \\
\hline
\end{tabular}

En qué época compran más carne de monte?

De que depende la demanda?

CONTROL Y DECOMISOS

Ha sido controlado por compra o venta de carne de monte?

$\square \quad$ Si $\quad \square$ No

Ha sido penalizado por el transporte o comercio de carne de monte?

$\square \quad$ SI

$\square$ No

Con que frecuencia piensa usted que ha sido controlado:

Como ha sido penalizado?

$$
\begin{array}{lll}
\square & \text { Multa } \quad \text { Cuanto pago? } \\
\square & \text { Cárcel } \quad \text { Cuanto tiempo estuvo en la carcel? } \\
\square & \text { Decomiso } \quad \text { Cuantos kilos le quitaron? } \\
\square & \text { Pago de contraparl Cuanto pago? } \\
\square & \text { Trabajo comunitarl Cuantos dias? } \\
\square & \text { otro } \quad \text { Explique }
\end{array}
$$

Cuántos controles hacen por mes? 
Lugar de la vivienda

Tiempo que ha vivido ahí

Casado:

$\square \mathrm{Si}$

$\square \quad$ No

No hijos:

Cuántas personas trabajan en su restaurante:

En la siguiente tabla ponga los datos de las personas que trabajan con usted:

\begin{tabular}{|l|l|l|l|l|l|}
\hline Nombre & Edad & Parentesco & Sexo & Educación & Ocupación** \\
\hline & & & & & \\
\hline & & & & & \\
\hline & & & & & \\
\hline
\end{tabular}

** categorias: pesca, artesanías, jornal, comercial, industria,

caza, industria, estudiante, hogar, otro 